\title{
The 6-Hydroxylation of Tryptamines by Microsomal Preparations from Human Liver Tissue Obtained at Routine Autopsy
}

The activity of the liver microsomal oxidative enzymes which are associated with the metabolism of drugs and foreign substances is species dependent ${ }^{1}$. One particular consequence of this is that the results of experiments in animals, or animal tissues in vitro, are not necessarily directly applicable to the human. The investigation of the hydroxylating ability of microsomal preparations from readily obtainable human liver tissue at routine postmortem examination was therefore undertaken ${ }^{2}$. The study involved the use of indolic substrates known to be transformed into 6-hydroxy derivatives by liver microsomes from rabbit, rat $^{3}$ and other species ${ }^{2}$. The enzyme system responsible for this conversion possesses several features characteristic of the liver drug processing enzymes ${ }^{2}$.

Method. In each case, an undiscoloured area at the lower border of the right hepatic lobe was selected and a wedge of liver weighing about $20 \mathrm{~g}$ was removed. The tissue was immediately rinsed in ice-cold $1.15 \%$ aqueous potassium chloride and it was carefully dissected from substrate, although they had no increased activity towards tryptamine or $N, N$-dimethyltryptamine. This is in keeping with our findings in rat and rabbit that phenobarbitone is a potent inducer of indole-6-hydroxylase activity against indolic substrates which normally are poorly hydroxylated but not against substrates which normally are highly susceptible ${ }^{2}$.

The absence of activity or low conversion rates in children paralleled the reported late appearance of several drug oxidases in the new-born and the young ${ }^{4}$.

The indole hydroxylating ability of rat and rabbit liver microsomal preparations deteriorates least rapidly when the preparations are kept deeply frozen 2,5 . Four human preparations, stored at $-20^{\circ} \mathrm{C}$, retained their hydroxylating activity for several months though to a relatively lesser extent than the animal preparations.

It appears therefore that it may be possible to use post-mortem human liver for the in vitro investigation of other microsomal reactions which 'detoxicate' drugs. Work on these lines is in progress ${ }^{6}$.

Hydroxylation of indolic derivatives by human liver in vitro

\begin{tabular}{|c|c|c|c|c|c|c|}
\hline \multirow[t]{2}{*}{ Clinical condition } & \multirow{2}{*}{$\begin{array}{l}\text { Age } \\
\text { (years) }\end{array}$} & \multirow[t]{2}{*}{$\operatorname{Sex}$} & \multirow{2}{*}{$\begin{array}{l}\mathrm{h} \text { after death } \\
\text { when liver tissue } \\
\text { was removed }\end{array}$} & \multicolumn{3}{|c|}{ 6-Hydroxy derivative from } \\
\hline & & & & tryptamine & $\begin{array}{l}N, N \text {-dimethyl- } \\
\text { tryptamine }\end{array}$ & $\begin{array}{l}\text { N-acetyl- } \\
\text { tryptophan }\end{array}$ \\
\hline $\begin{array}{l}\text { Hydrocephalus, Arnold- } \\
\text { Chiari syndrome }\end{array}$ & 1 & $\hat{o}$ & 19 & 0 & $\rightarrow$ & 0 \\
\hline Congenital heart disease & $15 / 12$ & $\delta$ & 20 & 0 & $-x^{x}$ & 0 \\
\hline Carcinoma bronchus & 54 & $\tilde{d}$ & 22 & 0.8 & 1.2 & -8 \\
\hline Myocardial infarction & 72 & $\partial$ & 21 & 0.15 & 0.6 & 0 \\
\hline Barbiturate overdosage & 55 & q & 21 & 0.5 & 0.85 & 0.9 \\
\hline Adenocarcinoma cervix uteri & 80 & $\dot{9}$ & $24^{1} / 2$ & 0.75 & 0.9 & -8 \\
\hline
\end{tabular}

. Values too low for accurate measurement.

fat, connective tissue and the larger blood vessels and bile ducts. Homogenization of finely-chopped $5 \mathrm{~g}$ portions in $40 \mathrm{ml}$ potassium chloride solution was carried out in a glass Potter-Elvehjem tube with a motor-driven Teflon pestle ( 2 passes). The homogenate was centrifuged at $10,000 \mathrm{~g}$ for $10 \mathrm{~min}$ at $0^{\circ} \mathrm{C}$. Volumes of microsomecontaining supernatant, equivalent to $0.375 \mathrm{~g}$ liver and strained of the floating layer of fat, were incubated with substrate $(10 \mu$ moles $), N A D P(0.5 \mu$ mole $)$, adenosine triphosphate ( $1 \mu$ mole) and nicotinamide, glucose-6-phosphate and magnesium chloride $(10 \mu$ moles each) in $0.2 \mathrm{M}$ pyrophosphate buffer pH 7.2 in a total volume of $4 \mathrm{ml}$ in open vessels in a metabolic shaker at $37.5^{\circ} \mathrm{C}$ for $1 \mathrm{~h}$. The reaction was stopped with trichloroacetic acid and the 6-hydroxyindoles were assayed by the diazotized sulphanilic acid procedure of JEPSON ${ }^{3}$.

Results. The amounts of hydroxylated product in $\mu$ moles/g wet liver $/ \mathrm{h}$ are shown in the Table.

The pattern of substrate activity was qualitatively similar to that obtained from rat $^{3}$ and hamster ${ }^{2}$ microsomes where the alkyltryptamines are more susceptible to hydroxylation than tryptamine itself.

As in the case with some other species, most of the human liver preparations only weakly catalysed the 6-hydroxylation of $N$-acetyl-tryptophan. However, microsomes from a patient who died from an overdose of barbiturate caused considerable hydroxylation of this
Riassunto. I preparati di microsomi del fegato umano ottenuto all'autopsia hanno la capacitá di ossidare diverse triptamine. Gli enzimi implicati sono simili a quelli che processano le sostanze straniere e farmacologiche. Ció dimostra ch'é possibile utilizzare questi preparati negli studi sul metabolismo dei farmaci.

\section{A. JACCARINI ${ }^{7}$ and J. B. JEPSON}

Courtauld Institute of Biochemistry, Middlesex

Hospital Medical School, London, W.7.

(England), 22 August 1967

1 G. P. Quinn, J. Axelrod and B. B. Brodre, Biochem. Pharmac. 1, 152 (1958); J. R. Gizletre, Fortschr. Arzneimitt Forsch, 6, 13 (1963); B. B. Brodie, Pharmacologist 6, 12 (1964).

2 A. JAccarini, Ph.D. Thesis, University of London (June 1966).

3 J. B. Jepson, P. Zaltzman and S. Udentriend, Biochim. biophys. Acta 62, 91 (1962).

4 J. R. Fouts and R. H. Adamson, Science 129, 897 (1959).

5 L. Leadbeater and D. R. Davies, Biochem. Pharmac. 13, 1607 (1964).

- This work was partially supported by a British Medical Association grant.

7 Present address: Evans Laboratories, Royal University of Malta, Valletta (Malta). 